Käyser, S.C., Schalk, B.W.M., Grauw, W.J.C. de, Schermer, T.R., Akkermans, R.P., Lenders, J.W.M., Deinum, J., Biermans, M.C.J. Is the plasma aldosterone-to-renin ratio associated with

\begin{tabular}{|l|l|}
\hline $\begin{array}{l}\text { Postprint } \\
\text { Version }\end{array}$ & 1.0 \\
\hline Journal website & $\frac{\text { https://academic.oup.com/fampra/advance-article- }}{\text { abstract/doi/10.1093/fampra/cmy039/4999776?redirectedFrom=fulltex }}$ \\
\hline Pubmed link & $\underline{\text { https://www.ncbi.nlm.nih.gov/pubmed/29788258 }}$ \\
\hline DOI & $10.1093 /$ fampra/cmy039
\end{tabular}

This is a NIVEL certified Post Print, more info at http://www.nivel.eu

\title{
Is the plasma aldosterone-to-renin ratio associated with blood pressure response to treatment in general practice?
}

\author{
SABINE C KÄYSERA, *, BIANCA W M SCHALKA, WiM J C DE GRAUWA, TJARD R \\ SCHERMERA,B, REINIER P AKKERMANSA,C, JACQUES W M LENDERSD,E, JAAP DEINUMD \\ AND MARION C J BIERMANSA
}

${ }^{a}$ Department of Primary and Community Care, Radboud University Medical Center, Nijmegen, The Netherlands,

${ }^{b}$ Netherlands Institute for Health Services Research (Nivel), Utrecht, The Netherlands, ${ }^{\mathrm{C}}$ Radboud Institute for Health Sciences, IQ Healthcare and

${ }^{d}$ Department of Internal Medicine, Radboud University Medical Center, Nijmegen, The Netherlands and

${ }^{e}$ Department of Internal Medicine III, University Hospital Carl Gustav Carus, Technische Universität Dresden, Dresden, Germany

\begin{abstract}
Background: Individualized antihypertensive treatment based on specific biomarkers such as renin may lead to more effective blood pressure control in patients with newly diagnosed essential hypertension. Recent studies suggested that the plasma aldosterone-to-renin ratio (ARR) may also be a candidate predictor for this purpose.

Objective: To assess whether the ARR is associated with the blood pressure response to antihypertensive treatment in patients with newly diagnosed hypertension.

Methods: In this prospective cohort study in primary care, we determined the ARR in patients with newly diagnosed hypertension prior to starting treatment. Treatment was categorized in five groups: no medication, use of angiotensinconverting-enzyme inhibitor or angiotensin receptor blocker, use of calcium channel blocker, use of diuretic, or use of beta blocker. We examined the relation between the ARR and blood pressure response within 1 year of treatment, taking into account the type of antihypertensive treatment and adjusting for gender, age, baseline blood pressure, and comorbidity.

Results: Out of 304 patients, we used 947 measurements (727 no medication, 220 medication) for analysis. There was no association between the ARR and the response in blood pressure, and this applied to each treatment group. Target
\end{abstract}


Käyser, S.C., Schalk, B.W.M., Grauw, W.J.C. de, Schermer, T.R., Akkermans, R.P., Lenders, J.W.M., Deinum, J., Biermans, M.C.J. Is the plasma aldosterone-to-renin ratio associated with

blood pressure, defined as systolic blood pressure $<140 \mathrm{mmHg}$, was reached in $31 \%$ of patients. There was no association between the ARR and reaching target blood pressure (OR 1.002, 95\% CI 0.983-1.022).

Conclusion: The ARR is not associated with the response in blood pressure within 1 year of antihypertensive treatment in primary care.

\section{INTRODUCTION}

Despite a wide variety of treatment options, target blood pressure is not reached in many patients with hypertension (1-3). This can be explained by various factors such as poor therapy adherence, secondary hypertension, comorbidity, and biological factors. Although numerous studies have demonstrated that all classes of antihypertensive drugs are similarly effective in reducing blood pressure $(4,5)$, it is also known that subgroups of patients respond better to specific classes of antihypertensive treatment. For example, in young hypertensive patients blood pressure is better controlled with an angiotensin-converting-enzyme inhibitor (ACEI), angiotensin receptor blocker (ARB) or a beta blocker $(6,7)$, and in black patients with hypertension blood pressure response is superior to a calcium channel blocker (CCB) or a diuretic (8). It is plausible to assume that personalized treatment guided by specific individual characteristics or biomarkers may lead to more effective blood pressure reduction $(9,10)$.

Of the studies that assessed biomarkers, several studies focussed on treatment guided by the activity of the renin-angiotensin-aldosterone system. In particular, renin has been studied as a biomarker to guide antihypertensive treatment. Patients with low renin levels were considered as having a high (intravascular) volume hypertension and therefore proposed to be candidates for diuretic treatment, while patients with high renin levels were considered more sensitive for treatment with a renin-lowering betablocker $(11,12)$.

The plasma aldosterone-to-renin ratio (ARR) reflects the level of aldosterone secretion in relation to renin secretion. The ARR is predominantly used as a screening test for primary aldosteronism, the most frequent cause of secondary hypertension $(13,14)$. The prevalence of primary aldosteronism is estimated to be $2-$ $5 \%$ in primary care, but this varies between studies due to differences in diagnostic methods $(15,16)$. Apart from primary aldosteronism some patients with essential hypertension may also display high ARR levels, although still in the normal range (17). Patients with a high ARR display an inappropriate high level of aldosterone in relation to renin. From the pathophysiological point of view, the high blood pressure in patients with a high ARR is considered to be due to an increased renal retention of sodium and water. Therefore, these patients may be particularly sensitive for treatment with diuretics and mineralocorticoid receptor antagonists (18). However, it is unclear whether or not the ARR can be used as a patient-specific biomarker in patients with newly diagnosed essential hypertension to predict the response to antihypertensive treatment.

For several reasons, it would be very helpful if an easy to use and cheap test would be available to predict blood pressure response to antihypertensive treatment. First, such a test, if effective, could markedly contribute to a more rapid optimization of antihypertensive treatment. Second, it could lead to less side-effects as not all drugs would need to be tried. Finally, such an approach might result in lower health care 
Käyser, S.C., Schalk, B.W.M., Grauw, W.J.C. de, Schermer, T.R., Akkermans, R.P., Lenders, J.W.M., Deinum, J., Biermans, M.C.J. Is the plasma aldosterone-to-renin ratio associated with

costs as patients achieve the target blood pressure more rapidly, thus reducing the associated hypertensive complications.

In this primary care observational study, we measured the ARR in patients with newly diagnosed hypertension prior to starting antihypertensive treatment. Our primary objective was to assess whether the ARR is associated with the blood pressure response in patients after a maximum of 1 year of treatment, and whether this association varied over the main specific classes of antihypertensive medication used in primary care (ACE-inhibitors, ARBs, beta blockers, CCBs, thiazide diuretics). Our secondary objective was to study the association between baseline ARR level and the number of patients that achieved a target systolic blood pressure of $<140 \mathrm{mmHg}$ within 1 year of treatment.

\section{METHODS}

\section{Study setting and study population}

In this prospective cohort study, we recruited patients from 55 primary care centres in the Nijmegen region in the Netherlands from August 1st 2013 to December 31st 2015. We included all patients over 18 years with newly diagnosed never treated hypertension. In the context of a previous study on the prevalence of primary aldosteronism, the participating patients had a measurement of plasma aldosterone and renin before starting antihypertensive treatment. This study is described in detail elsewhere (15). All patients had an office blood pressure measurement at baseline, at least 2 weeks of antihypertensive treatment, and at least one visit with office blood pressure measurement within 12 months of follow-up. For generalizability of the study results to patients with essential hypertension, patients with primary aldosteronism were excluded from this patient cohort as they require specific therapy according to the Endocrine Society guideline (19). Other exclusion criteria were: hypertensive crisis, heart failure classes II-IV (according to the New York Heart Association), estimated glomerular filtration rate of $<45 \mathrm{ml} / \mathrm{min} / 1.73 \mathrm{~m}^{2}$, pregnancy, breast feeding, diabetes mellitus, and severe comorbidity (defined as seriously interfering with diagnostics or therapy). All patients were on a liberal salt diet. This study was approved by the Ethics Committee of the Radboud University Medical Center and all patients gave informed consent. All general practitioners (GPs) approved extraction of their Electronic Health Records (EHRs) by written permission and informed their patients. Patients were given the opportunity to decline the use of their de-identified data. This method complies with the Code of Conduct for Health Research which has been approved by the Data Protection Authorities in conformity with the applicable Dutch privacy legislation. Reporting of this study is in concordance with the STrengthening the Reporting of OBservational studies in Epidemiology (STROBE) statement (20).

\section{Procedures}

Hypertension was defined according to the guideline of the European Society of Hypertension (1). In brief, hypertension was diagnosed if average office blood pressure of at least two blood pressure measurements per day was $\geq 140 / 90 \mathrm{mmHg}$ on two or more different visits within 6 months.

In the period from August 1st 2013 to December 14th 2014, plasma aldosterone was measured using the Coat-A-Count aldosterone radioimmunoassay (RIA) from Siemens Medical Solutions Diagnostics (Unites States of America). From December 
Käyser, S.C., Schalk, B.W.M., Grauw, W.J.C. de, Schermer, T.R., Akkermans, R.P., Lenders, J.W.M., Deinum, J., Biermans, M.C.J. Is the plasma aldosterone-to-renin ratio associated with

15th 2014 to December 31st 2015, plasma aldosterone was measured by the Active Aldosterone RIA kit from Beckman Coulter (Czech Republic). Plasma renin concentration was measured using the DSL-25100 active renin immunoradiometric assay (IRMA) from Diagnostic Systems Laboratories (United States of America).

\section{Data collection and processing}

We extracted data from the EHRs of the participating centres. The dataset included demographics, clinical characteristics, biochemical test results and prescribed medications. As in this study secondary analyses were performed, we refer to the parent study for the sample size calculation, and a full overview of the extraction process (15). In brief, patients were included if they had: (i) an International Classification of Primary Care (ICPC) (21) code hypertension (K86 or K87) between August 1st 2013 and December 31st 2015, or (ii) when an ICPC code was not available, if they had had two visits to their general practice documenting elevated blood pressure values as described in 'Procedures'. For each included patient, we extracted all office blood pressure values at baseline (i.e. the date of diagnosis of hypertension), and those obtained during 1 year after the initial diagnosis. Antihypertensive treatment was initiated by the GP, and comprised the use of an antihypertensive agent in combination with lifestyle advice according to the guideline. Blood pressure measurements were categorized in five treatment groups, in which each blood pressure measurement and the corresponding antihypertensive treatment was set. Because treatment could change over time, patients could change from treatment categories throughout the observation period and thus contribute to the analysis of more than one antihypertensive treatment. For the follow-up, we excluded blood pressure values that were measured within less than 2 weeks prior to the start or change of an antihypertensive agent, because we considered a time lapse of less than 14 days too short to achieve a maximal antihypertensive effect (1). Medication was encoded using the Anatomical Therapeutic Chemical (ATC) classification system: (i) angiotensin-converting-enzyme inhibitor or angiotensin receptor blocker, (ii) CCB, (iii) diuretic, or (iv) beta blocker (Supplementary Table 1). Blood pressure measurements without an ATC code were set in the "no medication' group.

\section{Data analysis}

We used the statistical package IBM SPSS Statistics version 22.0 to analyse the data. In case of normally distributed data, mean and SD were given. In case of skewed distribution, we calculated median and interquartile ranges. Next to patient level analyses, we analysed a dataset using all blood pressure measurements for each patient during follow-up. Relevant differences in baseline characteristics have been described. For the outcome variable delta systolic blood pressure, the mean differences with its $95 \%$ confidence interval $(95 \% \mathrm{CI})$ between the medication group(s) and the no medication group is presented. Because of the hierarchical structure of our study (repeated blood pressure measurements nested within patients), we performed multilevel analyses for the ARR and the blood pressure response. Statistical significance level was set at two-tailed $P$-value $<0.05$.

To assess if the ARR was associated with the response in blood pressure in relation to antihypertensive treatment, we used a multivariate multilevel linear regression analysis adjusted for gender, age, baseline systolic blood pressure and comorbidity entered into the random intercept model (22). The interaction term (treatment group 
Käyser, S.C., Schalk, B.W.M., Grauw, W.J.C. de, Schermer, T.R., Akkermans, R.P., Lenders, J.W.M., Deinum, J., Biermans, M.C.J. Is the plasma aldosterone-to-renin ratio associated with

by ARR) tests the difference in the association between the ARR and the response in systolic blood pressure for the five groups. The response in systolic blood pressure is defined as the baseline minus the follow-up systolic blood pressure measurement. We performed a sensitivity analysis to be able to compare our results with other literature, using logarithmic scale of ARR in relation with blood pressure decline (23).

To assess the association between the ARR and the number of patients on target blood pressure after 1 year of treatment, we used logistic regression analysis. Patients had reached target blood pressure if their last blood pressure measurement within 12 months from baseline was $<140 / 90 \mathrm{mmHg}$.

\section{RESULTS}

Of the initial 361 patients in whom an ARR was available, 57 patients had to be excluded from the analyses for the following reasons: (i) missing baseline or followup blood pressure measurements $(n=45)$, (ii) only blood pressure measurements during the use of multiple agents $(n=3)$ or (iii) a diagnosis of primary aldosteronism $(n=9)$. Consequently, 304 patients with a total of 947 blood pressure measurements were used for the analysis. Baseline characteristics were comparable between included $(n=304)$ and excluded patients $(n=57$; Supplementary Table 2$)$. The majority of patients had an ICPC code for hypertension $(n=210 ; 69.1 \%)$. Median number of blood pressure measurements per patient after baseline was two (interquartile range 1-4 measurements), with a range of 1-10 measurements. During the follow-up period, 110 patients (36.2\%) used antihypertensive medication and 194 did not. Figure 1 presents a flow diagram of the included patients in relation to blood pressure measurements. Table 1 shows patients characteristics for the medication and no medication group on patient level.

\section{[TABLE 1] [FIGURE 1]}

The number of blood pressure measurements for the medication and no medication group are shown in Table 2. Baseline characteristics between both groups were comparable. For delta systolic blood pressure, there was a clinically relevant difference between the groups of $-13.0 \mathrm{mmHg}(95 \% \mathrm{CI}-15.5$ to -10.5$)$.

Table 3 shows the baseline characteristics of each of the five groups. Prescribed medication $(n=220)$ consisted of $37.3 \%$ ACE-inhibitors or ARBs, $21.4 \% \mathrm{CCBs}$, $33.6 \%$ diuretics, and $7.7 \%$ of beta blockers. In the 'ACE-I or ARB' group more blood pressure measurements were available in males than in females, patients with blood pressure measurements in the diuretic group were slightly older, patients who receive $\mathrm{CCBs}$ had a higher aldosterone, patients who receive beta blockers had a higher renin, patients in the CCBs groups had a higher ARR, and baseline systolic blood pressure was comparable between all groups. Within each treatment group, systolic blood pressure showed a significant decline. Mean differences of response for each medication group compared to the no medication group (reference) are -16.4 (95\% CI -21.3 to -11.6$)$ for the CCB group, -15.2 (95\% CI -18.9 to -11.4$)$ for the ACE-I or ARB group, $-9.7(95 \% \mathrm{CI}-17.6$ to -1.7$)$ for the beta blocker group, and $-9.3 \mathrm{mmHg}(95 \% \mathrm{CI}-13.3$ to -5.3$)$ for the diuretic group. 
Käyser, S.C., Schalk, B.W.M., Grauw, W.J.C. de, Schermer, T.R., Akkermans, R.P., Lenders, J.W.M., Deinum, J., Biermans, M.C.J. Is the plasma aldosterone-to-renin ratio associated with

[TABLE 2][TABLE 3]

Multivariate multilevel linear regression analysis showed no association between the ARR and the blood pressure response within 1 year of treatment in the total group (regression coefficient $0.050,(95 \% \mathrm{CI}-0.009$ to 0.110$)$, Table 4$)$. There was no association between the ARR and the blood pressure response for the medication and no medication group (Table 4), but there was a significant difference in starting value of blood pressure response (i.e. a significant difference in intercept, $P<0.001$; Figure 2, Supplementary Tables 3 and 4). Subgroup analysis showed no significant association of the ARR and the response in blood pressure within each of the groups (Table 4). The interaction term between the ARR and the five treatment groups was non-significant $(P=0.77)$ with a significant intercept $(P<0.001$, Figure 2 , Supplementary Tables 5 and 6).

\section{[FIGURE 2. ]}

In our sensitivity analysis, we found no correlation between $\log \mathrm{ARR}$ and the response in blood pressure for all groups $(P=0.61)$.

During the last blood pressure measurement, 87 patients used antihypertensive medication (35 ACE-I or ARB, 14 CCB, 28 diuretic and 10 beta blocker). Of these patients target systolic blood pressure was reached in 27 patients $(31 \%)$. There was no association between ARR and the number of patients reaching target blood pressure (odds ratio $1.002,95 \%$ CI $0.983-1.022$ ).

\section{DISCUSSION}

\section{Summary}

In this study, we found no significant association between the ARR and the response in systolic blood pressure for the total medication group nor for the subgroups of antihypertensive agents after 1 year of treatment. Therefore, the ARR has no predictive value for the response in blood pressure to antihypertensive treatment in this primary care patient group. In patients that used antihypertensive agents target blood pressure was reached in $31 \%$ within 1 year after the initial diagnosis.

\section{Strengths and limitations}

A strong aspect of our study is the study setting of primary care as in many countries treatment of hypertension is started and monitored in primary care $(24,25)$.

Moreover, all included patients had not previously been treated with antihypertensive drugs at the time of aldosterone and renin measurement, which eliminates any confounding effects of these drugs on the ARR (19). Finally, we set relevant exclusion criteria by excluding groups which might confound the results and interpretation of the ARR, e.g. patients with diabetes.

As we included only patients with newly diagnosed hypertension and guidelines recommend to start lifestyle advice in newly diagnosed patients, the size of our study is limited to the medication groups. Since we did not include patients who needed referral to the hospital we did not have follow-up measurements of blood pressure in the primary care setting for these patients. Finally, 68 patients $(22.4 \%)$ with less than 1 year follow-up were included, because they were included in the last phase of our inclusion period. 
Käyser, S.C., Schalk, B.W.M., Grauw, W.J.C. de, Schermer, T.R., Akkermans, R.P., Lenders, J.W.M., Deinum, J., Biermans, M.C.J. Is the plasma aldosterone-to-renin ratio associated with

\section{Comparison with existing literature}

Previous studies have suggested that hypertensive patients with a high ARR respond favourably to spironolactone (26). Parthasarathy et al. studied the antihypertensive response of spironolactone compared to bendroflumethiazide in two groups of antihypertensive patients, one with high and one with low ARR, and found no predictive effect of the ARR. However, patients with high ARR were not tested for primary aldosteronism, and participants were not newly diagnosed hypertensive patients $(27,28)$. Prisant et al. performed an ad hoc analysis in which baseline ARR levels did not predict the antihypertensive response to eplerenone in combination with an ACE-I or ARB (29). Mahmud et al. (23) examined the effect of spironolactone on 30 hypertensive never treated patients, and found a significant correlation between the log ARR and the decline in blood pressure. All studies so far are uncontrolled and performed in a small number of patients. It is therefore not possible to draw conclusions on the value of the ARR in relation to the blood pressure response when mineralocorticoid receptor antagonists are used as monotherapy in essential hypertension. In our sensitivity analysis, we transformed the ARR in $\log$ ARR, but results remained non-significant. It should be noted that in our study not one patient was treated by mineralocorticoid antagonists, because in the Netherlands mineralocorticoid receptor antagonists are not used in primary practice for monotherapy in essential hypertension (30). As we provided no instructions about the use of specific antihypertensive agents, our study reflects daily clinical practice. Several large scale studies have promulgated the beneficial effects of thiazide diuretics in essential hypertension. Although a Cochrane review concluded that achieving target blood pressure is only partly responsible for the risk reduction of antihypertensive treatment, no inferences can be made about the association of the blood pressure lowering effect and the height of the ARR (31). In our study, the antihypertensive effect of diuretics was similar over the entire range of ARRs (Figure 2).

Although lifestyle advice is recommended by the guideline for each patient with hypertension we were not able to monitor this from the EHR data, however the decline in blood pressure in the no medication group could have been the result of this $(32,33)$.

\section{Implications for research and practice}

This explorative study in primary care does not provide evidence that a simple and cheap test like the ARR is helpful in predicting whether and which antihypertensive treatment in primary care is effective. In our study, no patients were treated with a mineralocorticoid receptor antagonist such as spironolactone, although previous studies have shown that a high ARR does predict a favourable blood pressure response to this drug $(23,26-28)$. Overall, these results cast doubt on the value of the ARR as a therapeutic marker (34). However, the ARR remains useful as a diagnostic marker for primary aldosteronism in hypertensive patients $(13,19)$.

\section{DECLARATION}

Funding: A grant for this study was obtained from the Radboudumc by JD.

Ethical approval: The study protocol was approved by the Medical Review Ethics

Committee Region Arnhem-Nijmegen (ID: NL40133.091.12).

Conflict of interest: none. 
Käyser, S.C., Schalk, B.W.M., Grauw, W.J.C. de, Schermer, T.R., Akkermans, R.P., Lenders, J.W.M., Deinum, J., Biermans, M.C.J. Is the plasma aldosterone-to-renin ratio associated with

blood pressure response to treatment in general practice? Family Practice: 2019, 36(2), 154-1617

\section{SUPPLEMENTARY MATERIAL}

Supplementary material is available at Family Practice online.

FUNDING: A GRANT FOR THIS STUDY WAS OBTAINED FROM THE RADBOUDUMC BY JD.

\section{ACKNOWLEDGEMENTS}

The authors wish to thank all general practitioners, their staff and the patients for taking part in our study. We also wish to thank the primary care based diagnostic centre Stichting Huisartsenlaboratorium Oost.

\section{REFERENCES}

1. Mancia G, Fagard R, Narkiewicz K et al.; Task Force Members. 2013 ESH/ESC Guidelines for the management of arterial hypertension: the Task Force for the management of arterial hypertension of the European Society of Hypertension (ESH) and of the European Society of Cardiology (ESC). J Hypertens 2013; 31: 1281-357.

2. Piepoli MF, Hoes AW, Agewall S et al.; ESC Scientific Document Group. 2016 European Guidelines on cardiovascular disease prevention in clinical practice: The Sixth Joint Task Force of the European Society of Cardiology and Other Societies on Cardiovascular Disease Prevention in Clinical Practice (constituted by representatives of 10 societies and by invited experts)Developed with the special contribution of the European Association for Cardiovascular Prevention \& Rehabilitation (EACPR). Eur Heart J 2016; 37: 2315-81.

3. James PA, Oparil S, Carter BL et al. 2014 evidence-based guideline for the management of high blood pressure in adults: report from the panel members appointed to the Eighth Joint National Committee (JNC 8). JAMA 2014; 311: 507-20.

4. Law MR, Morris JK, Wald NJ. Use of blood pressure lowering drugs in the prevention of cardiovascular disease: meta-analysis of 147 randomised trials in the context of expectations from prospective epidemiological studies. BMJ 2009; 338: b1665.

5. Turnbull F, Neal B, Ninomiya T et al.; Blood Pressure Lowering Treatment Trialists' Collaboration. Effects of different regimens to lower blood pressure on major cardiovascular events in older and younger adults: metaanalysis of randomised trials. $B M J$ 2008; 336: 1121-3.

6. Deary AJ, Schumann AL, Murfet H, Haydock SF, Foo RS, Brown MJ. Double-blind, placebo-controlled crossover comparison of five classes of antihypertensive drugs. $J$ Hypertens 2002; 20: 771-7.

7. Dickerson JE, Hingorani AD, Ashby MJ, Palmer CR, Brown MJ. Optimisation of antihypertensive treatment by crossover rotation of four major classes. Lancet 1999; 353: 2008-13.

8. Brewster LM, van Montfrans GA, Kleijnen J. Systematic review: antihypertensive drug therapy in black patients. Ann Intern Med 2004; 141: 614-27.

9. Preston RA, Materson BJ, Reda DJ et al. Age-race subgroup compared with renin profile as predictors of blood pressure response to antihypertensive therapy. Department of Veterans Affairs Cooperative Study Group on Antihypertensive Agents. JAMA 1998; 280: 1168-72.

10. van der Wel MC, Biermans M, Akkermans R, Lenders JWM, van Weel C, Deinum J. Patient characteristics do not predict the individual response to antihypertensive medication: a cross-over trial. Fam Pract 2018; 35: 67-73.

11. Spark RF, Melby JC. Hypertension and low plasma renin activity: presumptive evidence for mineralocorticoid excess. Ann Intern Med 1971; 75: 831-6. 
Käyser, S.C., Schalk, B.W.M., Grauw, W.J.C. de, Schermer, T.R., Akkermans, R.P., Lenders, J.W.M., Deinum, J., Biermans, M.C.J. Is the plasma aldosterone-to-renin ratio associated with

blood pressure response to treatment in general practice? Family Practice: 2019, 36(2), 154-161

12. Jose A, Crout JR, Kaplan NM. Suppressed plasma renin activity in essential hypertension. Roles of plasma volume, blood pressure, and sympathetic nervous system. Ann Intern Med 1970; 72: 9-16.

13. Raizman JE, Diamandis EP, Holmes D, Stowasser M, Auchus R, Cavalier E. A reninssance in primary aldosteronism testing: obstacles and opportunities for screening, diagnosis, and management. Clin Chem 2015; 61: 1022-7.

14. Montori VM, Young WF Jr. Use of plasma aldosterone concentration-toplasma renin activity ratio as a screening test for primary aldosteronism. A systematic review of the literature. Endocrinol Metab Clin North Am 2002; 31: 619-32, xi.

15. Kayser SC, Deinum J, de Grauw WJ et al. Prevalence of primary aldosteronism in primary care: a cross-sectional study. Br J Gen Pract 2018; 68: e114-22.

16. Kayser SC, Dekkers T, Groenewoud HJ et al. Study heterogeneity and estimation of prevalence of primary aldosteronism: a systematic review and meta-regression analysis. $J$ Clin Endocrinol Metab 2016; 101: 2826-35.

17. Brown JM, Robinson-Cohen C, Luque-Fernandez MA et al. The spectrum of subclinical primary aldosteronism and incident hypertension: a Cohort Study. Ann Intern Med 2017; 167: 630-41.

18. Williams B, MacDonald TM, Morant S et al.; British Hypertension Society' s PATHWAY Studies Group. Spironolactone versus placebo, bisoprolol, and doxazosin to determine the optimal treatment for drug-resistant hypertension (PATHWAY-2): a randomised, doubleblind, crossover trial. Lancet 2015; 386: 2059-68.

19. Funder JW, Carey RM, Mantero F et al. The management of primary aldosteronism: case detection, diagnosis, and treatment: an endocrine society clinical practice guideline. J Clin Endocrinol Metab 2016; 101: 1889-916.

20. von Elm E, Altman DG, Egger M et al.; STROBE Initiative. Strengthening the Reporting of Observational Studies in Epidemiology (STROBE) statement: guidelines for reporting observational studies. BMJ 2007; 335: 806-8.

21. Lamberts $\mathrm{H}$, Wood M, Hofmans-Okkes IM. International primary care classifications: the effect of fifteen years of evolution. Fam Pract 1992; 9: 330-9.

22. Snijders TA, Bosker RJ. Multilevel Analysis. An Antroduction to Basic and Advanced

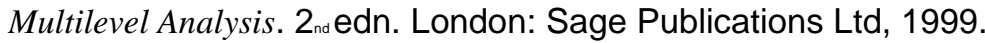

23. Mahmud A, Mahgoub M, Hall M, Feely J. Does aldosterone-to-renin ratio predict the antihypertensive effect of the aldosterone antagonist spironolactone? Am J Hypertens 2005; 18(12 Pt 1): 1631-5.

24. van Dis I, Kromhout D, Geleijnse JM, Boer JM, Verschuren WM. Evaluation of cardiovascular risk predicted by different SCORE equations: the Netherlands as an example. Eur J Cardiovasc Prev Rehabil 2010; 17: 244-9.

25. National Institute for Health and Care Excellence. NICE guideline. Hypertension in adults: diagnosis and management. 2011. https://www.nice.org.uk/guidance/cg127 (accessed 2 October 2017).

26. Lim PO, Jung RT, MacDonald TM. Is aldosterone the missing link in refractory hypertension?: aldosterone-to-renin ratio as a marker of inappropriate aldosterone activity. J Hum Hypertens 2002; 16: 153-8.

27. Parthasarathy HK, Alhashmi K, McMahon AD et al. Does the ratio of serum aldosterone to plasma renin activity predict the efficacy of diuretics in hypertension? Results of RENALDO. J Hypertens 2010; 28: 170-7.

28. Parthasarathy HK, Alhashmi K, McMahon AD et al. Does the aldosterone: renin ratio predict the efficacy of spironolactone over bendroflumethiazide in hypertension? A clinical trial protocol for RENALDO (RENin-ALDOsterone) study. BMC Cardiovasc Disord 2007; 7: 14.

29. Prisant LM, Krum H, Roniker B, Krause SL, Fakouhi K, He W. Can renin status predict the antihypertensive efficacy of eplerenone add-on therapy? J Clin Pharmacol 2003; 43: 1203-10.

30. Bazoukis G, Thomopoulos C, Tsioufis C. Effect of mineralocorticoid antagonists on blood pressure lowering: overview and meta-analysis of randomized controlled trials in hypertension. J Hypertens 2018; 36: 987-94. 
Käyser, S.C., Schalk, B.W.M., Grauw, W.J.C. de, Schermer, T.R., Akkermans, R.P., Lenders, J.W.M., Deinum, J., Biermans, M.C.J. Is the plasma aldosterone-to-renin ratio associated with

31. Wright JM, Musini VM. First-line drugs for hypertension. Cochrane Database Syst Rev 2009;

3: CD001841. doi: 10.1002/14651858. CD001841.pub2.

32. Aronow WS. Lifestyle measures for treating hypertension. Arch Med Sci 2017; 13: 1241-

3.

33. Appel LJ, Champagne CM, Harsha DW et al.; Writing Group of the PREMIER

Collaborative Research Group. Effects of comprehensive lifestyle modification on blood pressure control: main results of the PREMIER clinical trial. JAMA 2003; 289: 2083-93.

34. Atlas SA. Aldosterone to renin ratio as a predictor of diuretic response. Curr Hypertens Rep 2010; 12: 395-8.

\section{TABLES}

Table 1.

Baseline characteristics of included patients with newly diagnosed hypertension (1 August 2013 to 31 December 2015)

\begin{tabular}{|c|c|c|c|c|}
\hline Variable & $\begin{array}{l}\text { Patients with available } \\
\text { data (total/no } \\
\text { medication/medication) }\end{array}$ & $\begin{array}{l}\text { Total } \\
(n= \\
304)\end{array}$ & $\begin{array}{l}\text { No } \\
\text { medication } \\
(n=194)\end{array}$ & $\begin{array}{l}\text { Medication } \\
(n=110)\end{array}$ \\
\hline \multicolumn{5}{|c|}{ Demographics } \\
\hline $\begin{array}{l}\text { Male, } n \\
(\%)\end{array}$ & $304 / 194 / 110$ & $\begin{array}{l}154 \\
(50.7)\end{array}$ & $99(51.0)$ & $55(50.0)$ \\
\hline $\begin{array}{r}\text { Age } \\
\text { (years) }\end{array}$ & $304 / 194 / 110$ & $\begin{array}{l}53.4 \pm \\
11.4\end{array}$ & $52.8 \pm 11.3$ & $54.6 \pm 11.7$ \\
\hline $\begin{array}{l}\mathrm{BMI} \\
\left(\mathrm{kg} / \mathrm{m}^{2}\right), n \\
(\%)\end{array}$ & $205 / 134 / 71$ & & & \\
\hline$\leq 25$ & & $\begin{array}{l}44 \\
(21.5)\end{array}$ & $32(23.9)$ & $12(16.9)$ \\
\hline$>25-\leq 30$ & & $\begin{array}{l}93 \\
(45.4)\end{array}$ & $61(45.5)$ & $32(45.1)$ \\
\hline$>30$ & & $\begin{array}{l}68 \\
(33.2)\end{array}$ & $41(30.6)$ & $27(38.0)$ \\
\hline Smoking & $149 / 102 / 47$ & & & \\
\hline
\end{tabular}


Käyser, S.C., Schalk, B.W.M., Grauw, W.J.C. de, Schermer, T.R., Akkermans, R.P., Lenders, J.W.M., Deinum, J., Biermans, M.C.J. Is the plasma aldosterone-to-renin ratio associated with blood pressure response to treatment in general practice? Family Practice: 2019, 36(2), $154=1617$

\begin{tabular}{|c|l|l|l|l|}
\hline Variable & $\begin{array}{l}\text { Patients with available } \\
\text { data (total/no } \\
\text { medication/medication) }\end{array}$ & $\begin{array}{l}\text { Total } \\
(\boldsymbol{n}= \\
\mathbf{3 0 4})\end{array}$ & $\begin{array}{l}\text { No } \\
\text { medication } \\
(\boldsymbol{n}=\mathbf{1 9 4})\end{array}$ & $\begin{array}{l}\text { Medication } \\
(\boldsymbol{n}=\mathbf{1 1 0})\end{array}$ \\
\hline $\begin{array}{l}\text { status, } n \\
(\%)\end{array}$ & & $\begin{array}{l}34 \\
(22.8)\end{array}$ & $23(22.5)$ & $11(23.4)$ \\
\hline Current & & $\begin{array}{l}53 \\
(35.6)\end{array}$ & $35(34.3)$ & $18(38.3)$ \\
\hline Former & & $\begin{array}{l}62 \\
(41.6)\end{array}$ & $44(43.1)$ & $18(38.3)$ \\
\hline Never & & & & \\
\hline
\end{tabular}

Blood pressure

\begin{tabular}{|c|l|l|l|l|}
\hline $\begin{array}{c}\text { Systolic } \\
\text { BP (mmHg) }\end{array}$ & $304 / 194 / 110$ & $\begin{array}{l}163.8 \pm \\
13.1\end{array}$ & $\begin{array}{l}162.4 \pm \\
12.2\end{array}$ & $\begin{array}{l}166.4 \pm \\
14.3\end{array}$ \\
\hline $\begin{array}{c}\text { Diastolic } \\
\text { BP (mmHg) }\end{array}$ & $301 / 192 / 109$ & $\begin{array}{l}96.3 \pm \\
9.6\end{array}$ & $96.0 \pm 9.6$ & $96.8 \pm 9.8$ \\
\hline $\begin{array}{c}\text { Heart rate } \\
\text { (beats/min) }\end{array}$ & $181 / 113 / 68$ & $\begin{array}{l}75.3 \pm \\
12.7\end{array}$ & $73.5 \pm 12.7$ & $78.3 \pm 12.0$ \\
\hline
\end{tabular}

Biochemical parameters

\begin{tabular}{|c|l|l|l|l|}
\hline $\begin{array}{c}\text { Serum } \\
\text { potassium } \\
(\mathrm{mmol} / \mathrm{l})\end{array}$ & $302 / 193 / 109$ & $\begin{array}{l}4.43 \pm \\
0.34\end{array}$ & $4.42 \pm 0.34$ & $4.44 \pm 0.35$ \\
\hline $\begin{array}{c}\text { Serum } \\
\text { sodium } \\
(\mathrm{mmol} / \mathrm{l})\end{array}$ & $302 / 193 / 109$ & $\begin{array}{l}141.8 \pm \\
1.99\end{array}$ & $141.8 \pm 1.9$ & $141.7 \pm 2.1$ \\
\hline $\begin{array}{l}\text { Serum } \\
\text { creatinine } \\
(\mu \mathrm{mol} / \mathrm{l})\end{array}$ & $302 / 193 / 109$ & $\begin{array}{l}78.8 \pm \\
14.4\end{array}$ & $79.5 \pm 14.3$ & $77.5 \pm 14.6$ \\
\hline
\end{tabular}


Käyser, S.C., Schalk, B.W.M., Grauw, W.J.C. de, Schermer, T.R., Akkermans, R.P., Lenders, J.W.M., Deinum, J., Biermans, M.C.J. Is the plasma aldosterone-to-renin ratio associated with blood pressure response to treatment in general practice? Family Practice: 2019, 36(2), $154=1617$

\begin{tabular}{|c|c|c|c|c|}
\hline Variable & $\begin{array}{l}\text { Patients with available } \\
\text { data (total/no } \\
\text { medication/medication) }\end{array}$ & $\begin{array}{l}\text { Total } \\
(n= \\
304)\end{array}$ & $\begin{array}{l}\text { No } \\
\text { medication } \\
(n=194)\end{array}$ & $\begin{array}{l}\text { Medication } \\
(n=110)\end{array}$ \\
\hline $\begin{array}{l}\text { Aldosterone } \\
(\mathrm{pmol} / \mathrm{l})^{\mathrm{a}}\end{array}$ & $304 / 194 / 110$ & $\begin{array}{l}345.5 \\
(214.8 \\
460.0)\end{array}$ & $\begin{array}{l}337.5 \\
(200.5- \\
485.5)\end{array}$ & $\begin{array}{l}346.5 \\
(233.5- \\
440.3)\end{array}$ \\
\hline $\begin{array}{c}\text { Renin } \\
(\mathrm{pmol} / \mathrm{l})^{\mathrm{a}}\end{array}$ & $304 / 194 / 110$ & $\begin{array}{l}0.77 \\
(0.58- \\
1.31)\end{array}$ & $\begin{array}{l}0.75(0.58- \\
1.26)\end{array}$ & $\begin{array}{l}0.86(0.59- \\
1.43)\end{array}$ \\
\hline $\begin{array}{c}\text { ARR } \\
(\mathrm{pmol} / \mathrm{mU})^{\mathrm{a}}\end{array}$ & $304 / 194 / 110$ & $\begin{array}{l}25.2 \\
(14.2- \\
45.2)\end{array}$ & $\begin{array}{l}25.2(14.2- \\
49.7)\end{array}$ & $\begin{array}{l}25.5(13.8- \\
41.7)\end{array}$ \\
\hline $\begin{array}{l}\text { Serum } \\
\text { glucose } \\
(\mathrm{mmol} / \mathrm{l})\end{array}$ & 279/180/99 & $\begin{array}{l}5.4 \pm \\
0.9\end{array}$ & $5.3 \pm 0.8$ & $5.5 \pm 1.2$ \\
\hline
\end{tabular}

Cardiovascular morbidity

\begin{tabular}{|c|l|l|l|l|}
\hline $\begin{array}{c}\text { Atrial } \\
\text { fibrillation, } \\
(\%)\end{array}$ & $304 / 194 / 110$ & $2(0.7)$ & $1(0.5)$ & $1(0.9)$ \\
\hline $\begin{array}{c}\text { OSAS, } n \\
(\%)\end{array}$ & $304 / 194 / 110$ & $4(1.3)$ & $3(1.5)$ & $1(0.9)$ \\
\hline $\begin{array}{c}\text { MI, } n \\
(\%)\end{array}$ & $304 / 194 / 110$ & $2(0.7)$ & $1(0.5)$ & $1(0.9)$ \\
\hline $\begin{array}{c}\text { Stroke, } n \\
(\%)\end{array}$ & $304 / 194 / 110$ & $1(0.3)$ & 0 & $1(0.9)$ \\
\hline $\begin{array}{l}\text { Variable } \\
\text { Patients with available } \\
\text { data (total/no } \\
\text { medication/medication) }\end{array}$ & $\begin{array}{l}\text { Total } \\
(\boldsymbol{n}=\end{array}$ & $\begin{array}{l}\mathbf{3 0 4}) \\
\text { modication } \\
(\boldsymbol{n}=\mathbf{1 9 4})\end{array}$ & $\begin{array}{l}\text { Medication } \\
(\boldsymbol{n}=\mathbf{1 1 0})\end{array}$ \\
\hline
\end{tabular}

Demographics 
Käyser, S.C., Schalk, B.W.M., Grauw, W.J.C. de, Schermer, T.R., Akkermans, R.P., Lenders, J.W.M., Deinum, J., Biermans, M.C.J. Is the plasma aldosterone-to-renin ratio associated with blood pressure response to treatment in general practice? Family Practice: 2019, 36(2), $154=1617$

\begin{tabular}{|c|c|c|c|c|}
\hline Variable & $\begin{array}{l}\text { Patients with available } \\
\text { data (total/no } \\
\text { medication/medication) }\end{array}$ & $\begin{array}{l}\text { Total } \\
(n= \\
304)\end{array}$ & $\begin{array}{l}\text { No } \\
\text { medication } \\
(n=194)\end{array}$ & $\begin{array}{l}\text { Medication } \\
(n=110)\end{array}$ \\
\hline $\begin{array}{l}\text { Male, } n \\
(\%)\end{array}$ & $304 / 194 / 110$ & $\begin{array}{l}154 \\
(50.7)\end{array}$ & $99(51.0)$ & $55(50.0)$ \\
\hline $\begin{array}{r}\text { Age } \\
\text { (years) }\end{array}$ & $304 / 194 / 110$ & $\begin{array}{l}53.4 \pm \\
11.4\end{array}$ & $52.8 \pm 11.3$ & $54.6 \pm 11.7$ \\
\hline $\begin{array}{l}\mathrm{BMI} \\
\left(\mathrm{kg} / \mathrm{m}^{2}\right), n \\
(\%)\end{array}$ & $205 / 134 / 71$ & & & \\
\hline$\leq 25$ & & $\begin{array}{l}44 \\
(21.5)\end{array}$ & $32(23.9)$ & $12(16.9)$ \\
\hline$>25-\leq 30$ & & $\begin{array}{l}93 \\
(45.4)\end{array}$ & $61(45.5)$ & $32(45.1)$ \\
\hline$>30$ & & $\begin{array}{l}68 \\
(33.2)\end{array}$ & $41(30.6)$ & $27(38.0)$ \\
\hline $\begin{array}{l}\text { Smoking } \\
\text { status, } n \\
(\%)\end{array}$ & $149 / 102 / 47$ & & & \\
\hline Current & & $\begin{array}{l}34 \\
(22.8)\end{array}$ & $23(22.5)$ & $11(23.4)$ \\
\hline Former & & $\begin{array}{l}53 \\
(35.6)\end{array}$ & $35(34.3)$ & $18(38.3)$ \\
\hline Never & & $\begin{array}{l}62 \\
(41.6)\end{array}$ & $44(43.1)$ & $18(38.3)$ \\
\hline \multicolumn{5}{|c|}{ Blood pressure } \\
\hline $\begin{array}{c}\text { Systolic } \\
\text { BP }(\mathrm{mmHg})\end{array}$ & $304 / 194 / 110$ & $\begin{array}{l}163.8 \pm \\
13.1\end{array}$ & $\begin{array}{l}162.4 \pm \\
12.2\end{array}$ & $\begin{array}{l}166.4 \pm \\
14.3\end{array}$ \\
\hline
\end{tabular}


Käyser, S.C., Schalk, B.W.M., Grauw, W.J.C. de, Schermer, T.R., Akkermans, R.P., Lenders, J.W.M., Deinum, J., Biermans, M.C.J. Is the plasma aldosterone-to-renin ratio associated with blood pressure response to treatment in general practice? Family Practice: 2019, 36(2), $154=1617$

\begin{tabular}{|c|l|l|l|l|}
\hline Variable & $\begin{array}{l}\text { Patients with available } \\
\text { data (total/no } \\
\text { medication/medication) }\end{array}$ & $\begin{array}{l}\text { Total } \\
(\boldsymbol{n}= \\
\mathbf{3 0 4})\end{array}$ & $\begin{array}{l}\text { No } \\
\text { medication } \\
(\boldsymbol{n}=\mathbf{1 9 4})\end{array}$ & $\begin{array}{l}\text { Medication } \\
(\boldsymbol{n}=\mathbf{1 1 0})\end{array}$ \\
\hline $\begin{array}{c}\text { Diastolic } \\
\mathrm{BP}(\mathrm{mmHg})\end{array}$ & $301 / 192 / 109$ & $\begin{array}{l}96.3 \pm \\
9.6\end{array}$ & $96.0 \pm 9.6$ & $96.8 \pm 9.8$ \\
\hline $\begin{array}{c}\text { Heart rate } \\
\text { (beats/min) }\end{array}$ & $181 / 113 / 68$ & $\begin{array}{l}75.3 \pm \\
12.7\end{array}$ & $73.5 \pm 12.7$ & $78.3 \pm 12.0$ \\
\hline
\end{tabular}

Biochemical parameters

\begin{tabular}{|c|c|c|c|c|}
\hline $\begin{array}{l}\text { Serum } \\
\text { potassium } \\
(\mathrm{mmol} / \mathrm{l})\end{array}$ & $302 / 193 / 109$ & $\begin{array}{l}4.43 \pm \\
0.34\end{array}$ & $4.42 \pm 0.34$ & $4.44 \pm 0.35$ \\
\hline $\begin{array}{l}\text { Serum } \\
\text { sodium } \\
(\mathrm{mmol} / \mathrm{l})\end{array}$ & 302/193/109 & $\begin{array}{l}141.8 \pm \\
1.99\end{array}$ & $141.8 \pm 1.9$ & $141.7 \pm 2.1$ \\
\hline $\begin{array}{l}\text { Serum } \\
\text { creatinine } \\
(\mu \mathrm{mol} / 1)\end{array}$ & $302 / 193 / 109$ & $\begin{array}{l}78.8 \pm \\
14.4\end{array}$ & $79.5 \pm 14.3$ & $77.5 \pm 14.6$ \\
\hline $\begin{array}{l}\text { Aldosterone } \\
(\mathrm{pmol} / 1)^{\mathrm{a}}\end{array}$ & $304 / 194 / 110$ & $\begin{array}{l}345.5 \\
(214.8- \\
460.0)\end{array}$ & $\begin{array}{l}337.5 \\
(200.5- \\
485.5)\end{array}$ & $\begin{array}{l}346.5 \\
(233.5- \\
440.3)\end{array}$ \\
\hline $\begin{array}{c}\text { Renin } \\
(\mathrm{pmol} / \mathrm{l})^{\mathrm{a}}\end{array}$ & $304 / 194 / 110$ & $\begin{array}{l}0.77 \\
(0.58- \\
1.31)\end{array}$ & $\begin{array}{l}0.75(0.58- \\
1.26)\end{array}$ & $\begin{array}{l}0.86(0.59- \\
1.43)\end{array}$ \\
\hline $\begin{array}{c}\text { ARR } \\
(\mathrm{pmol} / \mathrm{mU})^{\mathrm{a}}\end{array}$ & $304 / 194 / 110$ & $\begin{array}{l}25.2 \\
(14.2- \\
45.2)\end{array}$ & $\begin{array}{l}25.2(14.2- \\
49.7)\end{array}$ & $\begin{array}{l}25.5(13.8- \\
41.7)\end{array}$ \\
\hline $\begin{array}{l}\text { Serum } \\
\text { glucose } \\
(\mathrm{mmol} / \mathrm{l})\end{array}$ & 279/180/99 & $\begin{array}{l}5.4 \pm \\
0.9\end{array}$ & $5.3 \pm 0.8$ & $5.5 \pm 1.2$ \\
\hline
\end{tabular}


Käyser, S.C., Schalk, B.W.M., Grauw, W.J.C. de, Schermer, T.R., Akkermans, R.P., Lenders, J.W.M., Deinum, J., Biermans, M.C.J. Is the plasma aldosterone-to-renin ratio associated with

\begin{tabular}{|c|l|l|l|l|}
\hline Variable & $\begin{array}{l}\text { Patients with available } \\
\text { data (total/no } \\
\text { medication/medication) }\end{array}$ & $\begin{array}{l}\text { Total } \\
(\boldsymbol{n}= \\
\mathbf{3 0 4})\end{array}$ & $\begin{array}{l}\text { No } \\
\text { medication } \\
(\boldsymbol{n}=\mathbf{1 9 4})\end{array}$ & $\begin{array}{l}\text { Medication } \\
(\boldsymbol{n}=\mathbf{1 1 0})\end{array}$ \\
\hline $\begin{array}{c}\text { Atrial } \\
\text { fibrillation, } \\
(\%)\end{array}$ & $304 / 194 / 110$ & $2(0.7)$ & $1(0.5)$ & $1(0.9)$ \\
\hline $\begin{array}{c}\text { OSAS, } n \\
(\%)\end{array}$ & $304 / 194 / 110$ & $4(1.3)$ & $3(1.5)$ & $1(0.9)$ \\
\hline $\begin{array}{l}\text { MI, } n \\
(\%)\end{array}$ & $304 / 194 / 110$ & $2(0.7)$ & $1(0.5)$ & $1(0.9)$ \\
\hline $\begin{array}{l}\text { Stroke, } n \\
(\%)\end{array}$ & $304 / 194 / 110$ & $1(0.3)$ & 0 & $1(0.9)$ \\
\hline
\end{tabular}

Data are presented as mean \pm standard deviation, unless stated otherwise. ARR, aldosterone-to-renin ratio; BP, office blood pressure; BMI, body mass index; MI, myocardial infarction; OSAS, obstructive sleep apnea syndrome.

${ }^{a}$ Median (interquartile range).

Table 2.

Baseline characteristics of all blood pressure measurements and response in systolic blood pressure for the medication and the no medication group (1 August 2013 to 31 December 2015)

\begin{tabular}{|l|l|l|}
\hline & All medication $(\boldsymbol{n = 2 2 0})$ & $\begin{array}{l}\text { No medication } \\
(\boldsymbol{n}=727)\end{array}$ \\
\hline Male, $n(\%)$ & $117(53.2)$ & $359(49.4)$ \\
\hline Age & $55.3 \pm 11.6$ & $53.3 \pm 11.7$ \\
\hline Aldosterone & $362.0(241.3-441.0)$ & $359.0(231.0-475.0)$ \\
\hline Renin $^{\mathrm{a}}$ & $0.86(0.61-1.33)$ & $0.77(0.58-1.29)$ \\
\hline
\end{tabular}


Käyser, S.C., Schalk, B.W.M., Grauw, W.J.C. de, Schermer, T.R., Akkermans, R.P., Lenders, J.W.M., Deinum, J., Biermans, M.C.J. Is the plasma aldosterone-to-renin ratio associated with blood pressure response to treatment in general practice? Family Practice: 2019, 36(2), 154-1617

\begin{tabular}{|c|c|c|}
\hline & All medication $(n=220)$ & $\begin{array}{l}\text { No medication } \\
(n=727)\end{array}$ \\
\hline $\mathrm{ARR}^{\mathrm{a}}$ & $27.2(13.5-44.3)$ & $27.0(14.5-46.7)$ \\
\hline Baseline SBP & $166.3 \pm 13.9$ & $164.0 \pm 13.3$ \\
\hline \multirow[t]{2}{*}{ Delta $\mathrm{SBP}^{\mathrm{b}}$} & $-18.3 \pm 18.4$ & $-5.3 \pm 16.0$ \\
\hline & All medication $(n=220)$ & $\begin{array}{l}\text { No medication } \\
(n=727)\end{array}$ \\
\hline Male, $n(\%)$ & $117(53.2)$ & $359(49.4)$ \\
\hline Age & $55.3 \pm 11.6$ & $53.3 \pm 11.7$ \\
\hline Aldosterone $^{\mathrm{a}}$ & $362.0(241.3-441.0)$ & $359.0(231.0-475.0)$ \\
\hline $\operatorname{Renin}^{\mathrm{a}}$ & $0.86(0.61-1.33)$ & $0.77(0.58-1.29)$ \\
\hline $\mathrm{ARR}^{\mathrm{a}}$ & $27.2(13.5-44.3)$ & $27.0(14.5-46.7)$ \\
\hline Baseline SBP & $166.3 \pm 13.9$ & $164.0 \pm 13.3$ \\
\hline Delta SBP ${ }^{b}$ & $-18.3 \pm 18.4$ & $-5.3 \pm 16.0$ \\
\hline
\end{tabular}

Data are presented as mean \pm standard deviation, unless stated otherwise. ARR, aldosterone-to-renin ratio. SBP, systolic blood pressure.

${ }^{a}$ Median (interquartile range).

'Delta SBP: the response in systolic blood pressure, defined as the baseline systolic blood pressure minus the follow-up systolic blood pressure.

Table 3.

Baseline characteristics of all blood pressure measurements and response in blood pressure for the different classes of antihypertensive agents and the no medication group (1 August 2013 to 31 December 2015) 
Käyser, S.C., Schalk, B.W.M., Grauw, W.J.C. de, Schermer, T.R., Akkermans, R.P., Lenders, J.W.M., Deinum, J., Biermans, M.C.J. Is the plasma aldosterone-to-renin ratio associated with

\begin{tabular}{|c|c|c|c|c|c|}
\hline Medication & $\begin{array}{l}\text { ACE-I or } \\
\text { ARB } \\
\left(n^{\mathrm{a}}=82\right)\end{array}$ & $\begin{array}{l}\text { CCB } \\
\left(n^{\mathrm{a}}=47\right)\end{array}$ & $\begin{array}{l}\text { Diuretics } \\
\left(n^{\mathrm{a}}=74\right)\end{array}$ & $\begin{array}{l}\text { BB } \\
\left(n^{\mathrm{a}}=17\right)\end{array}$ & $\begin{array}{l}\text { No } \\
\text { medication } \\
\left(n^{\mathrm{a}}=727\right)\end{array}$ \\
\hline Male, $n(\%)$ & $62(75.6)$ & $19(40.4)$ & $28(37.8)$ & $8(47.1)$ & $359(49.4)$ \\
\hline Age & $\begin{array}{l}54.2 \pm \\
11.7\end{array}$ & $\begin{array}{l}52.7 \pm \\
10.6\end{array}$ & $\begin{array}{l}59.3 \pm \\
10.6\end{array}$ & $\begin{array}{l}50.0 \pm \\
13.7\end{array}$ & $53.3 \pm 11.7$ \\
\hline Aldosterone $^{\mathrm{b}}$ & $\begin{array}{l}345.0 \\
(262.3- \\
443.8)\end{array}$ & $\begin{array}{l}415.0 \\
(359.0- \\
482.0)\end{array}$ & $\begin{array}{l}314.0 \\
(212.3- \\
437.8)\end{array}$ & $\begin{array}{l}363.0 \\
(250.0- \\
551.0)\end{array}$ & $\begin{array}{l}359.0 \\
(231.0- \\
475.0)\end{array}$ \\
\hline $\operatorname{Renin}^{\mathrm{b}}$ & $\begin{array}{l}1.1(0.6- \\
2.0)\end{array}$ & $\begin{array}{l}0.7(0.6- \\
1.2)\end{array}$ & $\begin{array}{l}0.8(0.6- \\
1.0)\end{array}$ & $\begin{array}{l}1.8(0.8- \\
3.1)\end{array}$ & $\begin{array}{l}0.8(0.6- \\
1.3)\end{array}$ \\
\hline $\mathrm{ARR}^{\mathrm{b}}$ & $\begin{array}{l}18.2 \\
(11.9- \\
39.7)\end{array}$ & $\begin{array}{l}41.7 \\
(27.7- \\
51.6)\end{array}$ & $\begin{array}{l}30.9(13.9- \\
41.7)\end{array}$ & $\begin{array}{l}17.0 \\
(8.1- \\
24.8)\end{array}$ & $\begin{array}{l}27.0(14.5- \\
46.7)\end{array}$ \\
\hline $\begin{array}{l}\text { Baseline } \\
\text { SBP }\end{array}$ & $\begin{array}{l}166.9 \pm \\
13.3\end{array}$ & $\begin{array}{l}170.1 \pm \\
17.7\end{array}$ & $\begin{array}{l}164.3 \pm \\
9.4\end{array}$ & $\begin{array}{l}161.4 \pm \\
19.2\end{array}$ & $164.0 \pm 13.3$ \\
\hline Delta $\mathrm{SBP}^{\mathrm{c}}$ & $\begin{array}{l}-20.5 \pm \\
17.0\end{array}$ & $\begin{array}{l}-21.7 \pm \\
23.3\end{array}$ & $\begin{array}{l}-14.6 \pm \\
15.6\end{array}$ & $\begin{array}{l}-15.0 \pm \\
19.0\end{array}$ & $-5.3 \pm 16.0$ \\
\hline Medication & $\begin{array}{l}\text { ACE-I or } \\
\text { ARB } \\
\left(n^{\mathrm{a}}=82\right)\end{array}$ & $\begin{array}{l}\text { CCB } \\
\left(n^{\mathrm{a}}=47\right)\end{array}$ & $\begin{array}{l}\text { Diuretics } \\
\left(n^{\mathrm{a}}=74\right)\end{array}$ & $\begin{array}{l}\text { BB } \\
\left(n^{\mathrm{a}}=17\right)\end{array}$ & $\begin{array}{l}\text { No } \\
\text { medication } \\
\left(n^{\mathrm{a}}=727\right)\end{array}$ \\
\hline Male, $n(\%)$ & $62(75.6)$ & $19(40.4)$ & $28(37.8)$ & $8(47.1)$ & $359(49.4)$ \\
\hline Age & $\begin{array}{l}54.2 \pm \\
11.7\end{array}$ & $\begin{array}{l}52.7 \pm \\
10.6\end{array}$ & $\begin{array}{l}59.3 \pm \\
10.6\end{array}$ & $\begin{array}{l}50.0 \pm \\
13.7\end{array}$ & $53.3 \pm 11.7$ \\
\hline Aldosterone $^{\mathrm{b}}$ & $\begin{array}{l}345.0 \\
(262.3- \\
443.8)\end{array}$ & $\begin{array}{l}415.0 \\
(359.0- \\
482.0)\end{array}$ & $\begin{array}{l}314.0 \\
(212.3- \\
437.8)\end{array}$ & $\begin{array}{l}363.0 \\
(250.0- \\
551.0)\end{array}$ & $\begin{array}{l}359.0 \\
(231.0- \\
475.0)\end{array}$ \\
\hline $\operatorname{Renin}^{\mathrm{b}}$ & $\begin{array}{l}1.1(0.6- \\
2.0)\end{array}$ & $\begin{array}{l}0.7(0.6- \\
1.2)\end{array}$ & $\begin{array}{l}0.8(0.6- \\
1.0)\end{array}$ & $\begin{array}{l}1.8(0.8- \\
3.1)\end{array}$ & $\begin{array}{l}0.8(0.6- \\
1.3)\end{array}$ \\
\hline
\end{tabular}


Käyser, S.C., Schalk, B.W.M., Grauw, W.J.C. de, Schermer, T.R., Akkermans, R.P., Lenders, J.W.M., Deinum, J., Biermans, M.C.J. Is the plasma aldosterone-to-renin ratio associated with

\begin{tabular}{|c|c|c|c|c|c|}
\hline Medication & $\begin{array}{l}\text { ACE-I or } \\
\text { ARB } \\
\left(n^{\mathrm{a}}=82\right)\end{array}$ & $\begin{array}{l}\text { CCB } \\
\left(n^{\mathrm{a}}=47\right)\end{array}$ & $\begin{array}{l}\text { Diuretics } \\
\left(n^{\mathrm{a}}=74\right)\end{array}$ & $\begin{array}{l}\text { BB } \\
\left(n^{\mathrm{a}}=17\right)\end{array}$ & $\begin{array}{l}\text { No } \\
\text { medication } \\
\left(n^{\mathrm{a}}=727\right)\end{array}$ \\
\hline $\mathrm{ARR}^{\mathrm{b}}$ & $\begin{array}{l}18.2 \\
(11.9- \\
39.7)\end{array}$ & $\begin{array}{l}41.7 \\
(27.7- \\
51.6)\end{array}$ & $\begin{array}{l}30.9(13.9- \\
41.7)\end{array}$ & $\begin{array}{l}17.0 \\
(8.1- \\
24.8)\end{array}$ & $\begin{array}{l}27.0(14.5- \\
46.7)\end{array}$ \\
\hline $\begin{array}{l}\text { Baseline } \\
\text { SBP }\end{array}$ & $\begin{array}{l}166.9 \pm \\
13.3\end{array}$ & $\begin{array}{l}170.1 \pm \\
17.7\end{array}$ & $\begin{array}{l}164.3 \pm \\
9.4\end{array}$ & $\begin{array}{l}161.4 \pm \\
19.2\end{array}$ & $164.0 \pm 13.3$ \\
\hline Delta $\mathrm{SBP}^{\mathrm{c}}$ & $\begin{array}{l}-20.5 \pm \\
17.0\end{array}$ & $\begin{array}{l}-21.7 \pm \\
23.3\end{array}$ & $\begin{array}{l}-14.6 \pm \\
15.6\end{array}$ & $\begin{array}{l}-15.0 \pm \\
19.0\end{array}$ & $-5.3 \pm 16.0$ \\
\hline
\end{tabular}

Data are presented as mean \pm standard deviation, unless stated otherwise. ACE-I, angiotensin-converting-enzyme inhibitor; ARB, angiotensin receptor blocker; ARR, aldosterone-to-renin ratio; $\mathrm{BB}$, beta blocker; $\mathrm{CCB}$, calcium channel blocker; SBP, systolic blood pressure.

${ }^{a}$ Number of systolic blood pressure measurements.

${ }^{\mathrm{b}}$ Median (interquartile range).

'Delta SBP: the response in systolic blood pressure, defined as the baseline systolic blood pressure minus the follow-up systolic blood pressure.

Table 4.

Multivariate multilevel linear regression analysis of the aldosterone-to-renin ratio and response in blood pressure

\begin{tabular}{|l|l|}
\hline & $\begin{array}{l}\text { Blood pressure response }^{\mathrm{a}} \\
(\boldsymbol{n}=947) \\
\boldsymbol{B}^{\mathrm{b}}(\mathbf{9 5 \%} \text { confidence interval })\end{array}$ \\
\hline ARR & $0.050(-0.009$ to 0.110$)$ \\
\hline ARR & \\
\hline
\end{tabular}


Käyser, S.C., Schalk, B.W.M., Grauw, W.J.C. de, Schermer, T.R., Akkermans, R.P., Lenders, J.W.M., Deinum, J., Biermans, M.C.J. Is the plasma aldosterone-to-renin ratio associated with blood pressure response to treatment in general practice? Family Practice: 2019, 36(2), 154-1617

\begin{tabular}{|c|c|}
\hline & $\begin{array}{l}\text { Blood pressure response }^{\mathrm{a}} \\
(n=947) \\
B^{\mathrm{b}}(95 \% \text { confidence interval })\end{array}$ \\
\hline All medication & $0.048(-0.044$ to 0.139$)$ \\
\hline No medication & $0.047(-0.014$ to 0.108$)$ \\
\hline ARR & \\
\hline ACE-I or ARB & $0.110(-0.019$ to 0.239$)$ \\
\hline $\mathrm{CCB}$ & $0.010(-0.186$ to 0.206$)$ \\
\hline Diuretic & $-0.005(-0.155$ to 0.145$)$ \\
\hline Beta blocker & $0.155(-0.480$ to 0.789$)$ \\
\hline \multirow[t]{2}{*}{ No medication } & $0.049(-0.012$ to 0.110$)$ \\
\hline & $\begin{array}{l}\text { Blood pressure response }^{\mathrm{a}} \\
(n=947) \\
\boldsymbol{B}^{\mathrm{b}}(95 \% \text { confidence interval })\end{array}$ \\
\hline ARR & $0.050(-0.009$ to 0.110$)$ \\
\hline \multicolumn{2}{|l|}{ ARR } \\
\hline All medication & $0.048(-0.044$ to 0.139$)$ \\
\hline No medication & $0.047(-0.014$ to 0.108$)$ \\
\hline \multicolumn{2}{|l|}{ ARR } \\
\hline ACE-I or ARB & $0.110(-0.019$ to 0.239$)$ \\
\hline $\mathrm{CCB}$ & $0.010(-0.186$ to 0.206$)$ \\
\hline Diuretic & $-0.005(-0.155$ to 0.145$)$ \\
\hline Beta blocker & $0.155(-0.480$ to 0.789$)$ \\
\hline
\end{tabular}


Käyser, S.C., Schalk, B.W.M., Grauw, W.J.C. de, Schermer, T.R., Akkermans, R.P., Lenders, J.W.M., Deinum, J., Biermans, M.C.J. Is the plasma aldosterone-to-renin ratio associated with blood pressure response to treatment in general practice? Family Practice: 2019, 36(2), 154-1617

\begin{tabular}{|c|l|}
\hline & $\begin{array}{l}\text { Blood pressure response } \\
(\boldsymbol{n}=947) \\
\boldsymbol{B}^{\mathrm{b}}(95 \% \text { confidence interval })\end{array}$ \\
\hline No medication & $0.049(-0.012$ to 0.110$)$ \\
\hline
\end{tabular}

ACE-I, angiotensin-converting-enzyme inhibitor; ARB, angiotensin receptor blocker; ARR, aldosterone-to-renin ratio; BB, beta blocker; $\mathrm{CCB}$, calcium channel blocker; $\beta$, regression coefficient.

${ }^{a}$ Blood pressure response in systolic blood pressure, defined as the baseline minus the follow-up systolic blood pressure measurement.

${ }^{\mathrm{b}}$ Adjusted for age, gender and baseline blood pressure. 